\title{
Risk factors for tumors or leukemia development in the first two years of life
}

\author{
Hana Wiedermannovaa, ${ }^{a, b}$, Peter Mudry ${ }^{b, c, d \#, ~ J a n ~ P a v l i c e k e, f, ~ H a n a ~ T o m a s k o v a ~}{ }^{g}$, Andrea Hladikova ${ }^{h}$, Hana Palova', \\ Petra Vesela ${ }^{\mathrm{i}}$, Ondrej Slaby ${ }^{\mathrm{ij}}$, Jaroslav Sterba ${ }^{\mathrm{b}, \mathrm{c}, \mathrm{d}}$
}

\begin{abstract}
Objectives. The objective of this study was to determine the incidence of neoplastic diseases and associated risk factors in the early stages of life.

Methods. Data were retrospectively assessed in 730,000 live births between 2000 and 2019 . The occurrence of tumors was monitored in the neonatal, infant (1-12 months), and toddler (13-24 months) periods. Risk factors were divided into demographic, internal, and environmental factors. The control group consisted of subjects in the same age category without oncological diseases.
\end{abstract}

Results. A total of 452 neoplastic diseases were diagnosed in the study sample. In total, 24\% (110/452) manifested during the neonatal period, $45 \%$ (203/452) in infants, and 31\% (139/452) at the age of 13-24 months. Any genetic disease (OR 26.68; 95\% Cl 7.64-93.12) and medications used by the mother (OR 3.07; 95\% Cl 1.32-7.15) were identified as risk factors.

Without adjustment for all factors, asphyxia in the first minute, a younger age of the mother, lower pregnancy, and the presence of a congenital defect manifested themselves as risk factors.

Conclusions. The highest risk factors for the development of early childhood tumors were identified as with medications used by the mother before or during pregnancy and genetic diseases.

Key words: neoplastic disease, epidemiology, risk factors, early-aged period

Received: October 15, 2021; Revised: January 23, 2022; Accepted: January 25, 2022; Available online: February 11, 2022

https://doi.org/10.5507/bp.2022.004

(c) 2022 The Authors; https://creativecommons.org/licenses/by/4.0/

${ }^{a}$ Department of Neonatology, University Hospital Ostrava, Ostrava, Czech Republic

${ }^{b}$ Faculty of Medicine, Masaryk University, Brno, Czech Republic

'Department of Pediatric Oncology, University Hospital Brno, Brno, Czech Republic

dICRC, St. Anne's University Hospital Brno, Brno, Czech Republic

${ }^{e}$ Department of Pediatrics and Prenatal Cardiology, University Hospital Ostrava, Ostrava, Czech Republic

${ }^{f}$ Biomedical Research Center, University Hospital Hradec Kralove, Hradec Kralove, Czech Republic

${ }^{9}$ Department of Epidemiology and Public Health, Faculty of Medicine, University of Ostrava, Ostrava, Czech Republic

${ }^{h}$ Department of Medical Genetics, University Hospital of Ostrava, Ostrava, Czech Republic

${ }^{i}$ CEITEC - Central European Institute of Technology, Masaryk University, Brno, Czech Republic

'Department of Biology, Faculty of Medicine, Masaryk University, Brno, Czech Republic

"These authors contributed equally

Corresponding author: Jan Pavlicek, e-mail:jan.pavlicek@fno.cz

\section{INTRODUCTION}

Cancer is the second most common cause of death during childhood ${ }^{1-3}$. The incidence of neonatal tumors is estimated to be $2 \%$ of all childhood tumors. Neonatal tumors differ from childhood tumors in etiopathogenesis, localization, behavior, treatment, and response to treatment, as well as in long-term prognosis ${ }^{48}$.

The etiology of tumors is multifactorial. Tumors occurring at an early age are assumed to develop in connection with pathological processes occurring in the fetus in utero. Non-hereditary causes most often include environmental risk factors, demographic factors, and internal risk factors 9 . The emphasis on hereditary factors has increased, as they are considered to be one of the main causes of tumor development in children ${ }^{6-10}$. Hereditary causes are mostly disorders of the mechanisms regulating cell proliferation, and epigenetics play an important role. Congenital malformations and syndromes also have potential hereditary causes ${ }^{4,9,10}$.

The objective of this study was to assess the risk factors that can be associated with the development of tumors and leukemias in neonates, infants, and early childhood.

\section{METHODOLOGY}

Data were assessed retrospectively based on a cohort of children born between 2000 and 2019 in a population of 730,000 live births. This study was conducted at the Department of Neonatology, University Hospital Ostrava, and the Department of Pediatric Oncology, University Hospital Brno, Czech Republic. These hospitals serve a population of approximately 4,000,000 inhabitants, with 37,000 live births per year. Tumor incidence was moni- 
tored in neonates, infants aged 1-12 months, and toddlers aged 13-24 months. The participation rate was over 95\% as this is the geographical coverage of the region by the Department of Pediatric Oncology, University Hospital Brno. Data were retrospectively verified in the national registry of the pediatrics tumors.

The risk factors were divided into three categories ${ }^{9}$ : demographic, internal, and environmental. Demographic factors included maternal and paternal age, divided into six categories: <19, 20-24, 25-29, 30-34, 35-39, and >40 years. Internal factors included birth weight (five categories: $<1500$ g, 1501-2000, 2001-2500, 2501-4000, and $>4000 \mathrm{~g}$ ), maturity of the newborn (three categories: mature newborn, gestational week from $37+0$; mildly immature, $32+0$ to $36+6$; moderately and severely immature, before week $31+6)$, relationship between the birth weight and gestational week (three categories: large for gestational age, when birth weight exceeded the $90^{\text {th }}$ percentile for the gestational week [LGA], appropriate for gestational age, when birth weight was between the $10^{\text {th }}$ and $90^{\text {th }}$ percentile for the gestational week [AGA], small for gestational age [SGA], when birth weight was below $10^{\text {th }}$ percentile for the gestational week. Fenton growth charts were used to derive percentiles of birth weight), pregnancy order and parity (four categories: first, second, third, and fourth and higher), conception method (natural or in vitro fertilization [IVF]), pregnancy multiplicity (singleton or twins), Apgar score (AS) at 1, 5, and 10 min (four categories of asphyxia: severe $0-3$, moderate $4-5$, mild $6-7$, and physiological adaptation $8-10$ points), and incidence of congenital malformation (using the International Classification of Diseases and Related Health Problems, all defects were determined at the time of birth), or genetic syndrome. Environmental factors included the following: use of medications, nicotine, alcohol, or illicit drug abuse by the mother. Risk factors of the mother's working environment were studied. Occupations associated with risk factors for carcinogenicity were defined and consulted by the National Teratology Service and assessed by geneticists (hair dying, horticulture, agriculture, rubber industry, medicine, chemicals).

Data were acquired from medical records of both the neonatology center and tertiary oncology center where patients with tumors were diagnosed and treated. The control group consisted of randomly selected subjects. The sample size of the control group was chosen to be three times larger than the sample size of the case group to reach an appropriate power of the statistical test. In other words, for every child with a tumor, three children of the same age without tumor were included in the control group.

This study was reviewed by the institutional review board and approved by the local ethics committee (No. 1028/2020). No consent from patients (parents/guardians) was required since data was collected only from clinical charts.

\section{Statistical analysis}

Descriptive analysis was used to describe the sample. For statistical analysis, Pearson's chi-square test (chi2) test, Fisher's exact test, and Two-sample Mann-Whitney test were used as appropriate. Potential risk factors showing statistically significant differences were selected and further analyzed using a logistic regression model. The output consisted crude Odds Ratio (OR) and adjusted OR with 95\% Confidence Intervals derived from a fully adjusted (pregnancy order, Apgar score $1 \mathrm{~min}$, a congenital defect, genetic pathology, and medication) model. The category with the lowest risk was selected as the base category (marked 1+). For the other categories, the OR reflects the level of the risk compared to the base category. Risk and protective factors were determined based on the levels of the OR. The level of significance $\alpha$ for the probability of a type-I error ( $P$ value) was set at 0.05 . Analyses were performed using STATA software (Stata version 14; StataCorp LP, College Station, TX, USA).

Table 1. Type and frequence of the tumor and leukemia, divided by International Classification of Childhood cancer, third edition.

\begin{tabular}{|c|c|c|c|}
\hline Type of tumor or leukemia $(n=452)$ & $\begin{array}{c}\text { Newborns } \\
\mathrm{n}(\%)\end{array}$ & $\begin{array}{c}\text { Infants } \\
\mathrm{n}(\%)\end{array}$ & $\begin{array}{c}\text { Toddlers } \\
\mathrm{n}(\%)\end{array}$ \\
\hline Leukemias, Myeloproliferative and Myelodysplastic Disease $(n=36)$ & $5(14)$ & $13(36)$ & $18(50)$ \\
\hline Lymphomas and Reticuloendothelial Neoplasms $(n=24)$ & $7(29)$ & $7(29)$ & $10(42)$ \\
\hline CNS and Miscalleneous Intracranial and Intraspinal Neoplasm $(n=69)$ & $9(13)$ & $28(41)$ & $32(46)$ \\
\hline Neuroblastoma and Other peripheral Nervous Cell Tumors (n=93) & $20(21)$ & $52(56)$ & $21(23)$ \\
\hline Retinoblastoma $(\mathrm{n}=19)$ & $1(6)$ & $9(47)$ & $9(47)$ \\
\hline Renal Tumors $(\mathrm{n}=31)$ & $3(10)$ & $16(52)$ & $12(38)$ \\
\hline Hepatic Tumors $(n=14)$ & $2(14)$ & $6(43)$ & $6(43)$ \\
\hline Malignant Bone Tumors $(n=6)$ & $0(0)$ & $4(67)$ & $2(33)$ \\
\hline Soft Tissue and Other Extraosseous Sarcomas $(n=44)$ & $18(41)$ & $17(39)$ & $9(20)$ \\
\hline Germ Cell Tumors, Trophoblastic Tumors and Neoplasms of Gonads $(\mathrm{n}=36$ ) & $15(42)$ & $15(42)$ & $6(16)$ \\
\hline Other Malignant Epithelial Neoplasms and Malignant Melanomas (n=2) & $0(0)$ & $2(100)$ & $0(0)$ \\
\hline Other and Unspecified Malignant Neoplasms $(n=4)$ & $2(50)$ & $0(0)$ & $2(50)$ \\
\hline Not classified - benign form of tumors $(n=74)$ & $28(38)$ & $34(46)$ & $12(16)$ \\
\hline
\end{tabular}


Table 2. Studied risk factors.

\begin{tabular}{|c|c|c|c|c|c|c|}
\hline \multirow[t]{2}{*}{ Risk factors } & & \multicolumn{2}{|c|}{ Tumor group } & \multicolumn{2}{|c|}{ Control group } & \multirow[t]{2}{*}{$P$} \\
\hline & & $\mathrm{n}$ & $\%$ & $\mathrm{n}$ & $\%$ & \\
\hline \multicolumn{7}{|c|}{ Demographic factors } \\
\hline \multirow[t]{2}{*}{ Sex } & male & 231 & 51.1 & 670 & 52.4 & 0.640 \\
\hline & female & 221 & 48.9 & 609 & 47.6 & \\
\hline \multirow[t]{6}{*}{ Age of mother } & 19 years or less & 8 & 2.2 & 21 & 1.6 & $<0.001$ \\
\hline & $20-24$ & 45 & 12.2 & 91 & 7.1 & \\
\hline & $25-29$ & 131 & 35.5 & 367 & 28.7 & \\
\hline & $30-34$ & 126 & 34.1 & 487 & 38.1 & \\
\hline & $35-39$ & 49 & 13.3 & 240 & 18.8 & \\
\hline & 40 and more & 10 & 2.7 & 73 & 5.7 & \\
\hline \multirow[t]{6}{*}{ Age of father } & 19 years or less & 2 & 0.6 & 11 & 0.9 & 0.1 \\
\hline & $20-24$ & 14 & 4.2 & 48 & 3.8 & \\
\hline & $25-29$ & 97 & 29.3 & 249 & 19.5 & \\
\hline & $30-34$ & 113 & 34.1 & 411 & 32.2 & \\
\hline & $35-39$ & 69 & 20.8 & 332 & 26.0 & \\
\hline & 40 and more & 36 & 10.8 & 225 & 17.6 & \\
\hline \multirow{3}{*}{$\begin{array}{l}\text { Age difference } \\
\text { of parents }\end{array}$} & older mother (more than 10 years) & 1 & 0.3 & 9 & 0.7 & 0.595 \\
\hline & intermediate ( -9 to 9 years) & 297 & 90.0 & 1157 & 90.7 & \\
\hline & older father (more than 10 years) & 32 & 9.7 & 110 & 8.6 & \\
\hline \multicolumn{7}{|l|}{ Internal factors } \\
\hline Pregnancy & 1 & 195 & 45.0 & 469 & 36.7 & $<0.001$ \\
\hline \multirow[t]{3}{*}{ order } & 2 & 153 & 35.3 & 454 & 35.5 & \\
\hline & 3 & 40 & 9.2 & 216 & 16.9 & \\
\hline & 4 and more & 45 & 10.4 & 140 & 10.9 & \\
\hline Parity & 1 & 214 & 49.7 & 599 & 46.8 & 0.323 \\
\hline \multirow[t]{3}{*}{ order } & 2 & 157 & 36.4 & 504 & 39.4 & \\
\hline & 3 & 41 & 9.5 & 137 & 10.7 & \\
\hline & 4 and more & 19 & 4.4 & 39 & 3.0 & \\
\hline \multirow[t]{2}{*}{ Twins } & no & 430 & 95.8 & 1195 & 93.4 & 0.72 \\
\hline & yes & 19 & 4.2 & 84 & 6.6 & \\
\hline \multirow{2}{*}{$\begin{array}{l}\text { In vitro } \\
\text { fertilization }\end{array}$} & no & 426 & 95.3 & 1235 & 96.6 & 0.385 \\
\hline & yes & 21 & 4.7 & 44 & 3.4 & \\
\hline \multirow[t]{5}{*}{ Birth weight } & less than $1500 \mathrm{~g}$ & 9 & 2.0 & 43 & 3.4 & 0.243 \\
\hline & $1501-2000 \mathrm{~g}$ & 10 & 2.3 & 52 & 4.1 & \\
\hline & $2001-2500 \mathrm{~g}$ & 33 & 7.5 & 95 & 7.4 & \\
\hline & $2501-4000 \mathrm{~g}$ & 347 & 78.5 & 978 & 76.5 & \\
\hline & more than $4000 \mathrm{~g}$ & 43 & 9.7 & 111 & 8.7 & \\
\hline Gestational & less than $31+6$ & 14 & 3.2 & 61 & 4.8 & 0.89 \\
\hline week & $32-36+6$ & 59 & 13.3 & 209 & 16.3 & \\
\hline & 37 and more & 371 & 83.6 & 1009 & 78.9 & \\
\hline Newborn's trophic & small for $\mathrm{GA}$ & 46 & 10.4 & 126 & 9.9 & 0.938 \\
\hline & appropriate for GA & 355 & 80.3 & 1031 & 80.6 & \\
\hline & large for GA & 41 & 9.3 & 122 & 9.5 & \\
\hline Apgar & $0-3$ & 5 & 6.9 & 16 & 1.3 & $<0.001$ \\
\hline score & $4-5$ & 6 & 8.3 & 32 & 2.5 & \\
\hline $1 \mathrm{~min}$ & $6-7$ & 8 & 11.1 & 79 & 6.2 & \\
\hline & $8-10$ & 53 & 73.6 & 1152 & 90.1 & \\
\hline Apgar & $0-3$ & 1 & 1.4 & 2 & 0.2 & 0.66 \\
\hline score & $4-5$ & 0 & 0.0 & 4 & 0.3 & \\
\hline $5 \mathrm{~min}$ & $6-7$ & 4 & 5.6 & 33 & 2.6 & \\
\hline & $8-10$ & 67 & 93.1 & 1240 & 97.0 & \\
\hline Apgar & $0-3$ & 1 & 1.4 & 0 & 0.0 & 0.037 \\
\hline score & $4-5$ & 0 & 0.0 & 2 & 0.2 & \\
\hline $10 \mathrm{~min}$ & $6-7$ & 1 & 1.4 & 7 & 0.5 & \\
\hline & $8-10$ & 70 & 97.2 & 1270 & 99.3 & \\
\hline Death & no & 419 & 92.7 & 1271 & 99.6 & $<0.001$ \\
\hline & yes & 33 & 7.3 & 5 & 0.4 & \\
\hline Congenital & no & 421 & 94.2 & 1250 & 97.7 & $<0.001$ \\
\hline defect & yes & 26 & 5.8 & 29 & 2.3 & \\
\hline Genetic & no & 420 & 92.9 & 1274 & 99.6 & $<0.001$ \\
\hline pathology & yes & 32 & 7.1 & 5 & 0.4 & \\
\hline
\end{tabular}


Table 2. (Continued.)

\begin{tabular}{|c|c|c|c|c|c|c|}
\hline \multicolumn{7}{|c|}{ Environmental risk factors in mother } \\
\hline \multirow[t]{2}{*}{ Smoking } & no & 412 & 92.8 & 1152 & 90.1 & 0.88 \\
\hline & yes & 32 & 7.2 & 127 & 9.9 & \\
\hline \multirow[t]{2}{*}{ Medication } & no & 403 & 91.4 & 1235 & 96.6 & $<0.001$ \\
\hline & yes & 38 & 8.6 & 44 & 3.4 & \\
\hline \multirow{2}{*}{$\begin{array}{l}\text { Alcohol } \\
\text { drugs }\end{array}$} & no & 444 & 99.6 & 1267 & 99.1 & 0.321 \\
\hline & yes & 2 & 0.4 & 12 & 0.9 & \\
\hline \multirow[t]{6}{*}{ Risk work processes } & hairdressers/hair dying & 8 & 47.1 & 0 & 0.0 & $\mathrm{~N} / \mathrm{A}$ \\
\hline & horticulture & 3 & 17.6 & 2 & 10.0 & \\
\hline & agriculture & 1 & 5.9 & 0 & 0.0 & \\
\hline & rubber industry & 1 & 5.9 & 0 & 0.0 & \\
\hline & medicine & 1 & 5.9 & 17 & 85.0 & \\
\hline & chemicals & 3 & 17.6 & 1 & 5.0 & \\
\hline
\end{tabular}

N/A: not applicable GA: gestational age

Table 3. Detail analysis of significant risk factors.

\begin{tabular}{|c|c|c|c|c|c|c|c|c|c|}
\hline \multirow[t]{2}{*}{ Risk factor } & & \multicolumn{4}{|c|}{ Crude } & \multicolumn{4}{|c|}{ Adjustment for all factors } \\
\hline & & OR & & & $P$ & OR & & & $P$ \\
\hline \multirow[t]{4}{*}{ Pregnancy order } & 1 & $1+$ & & & & $1+$ & & & \\
\hline & 2 & 0.81 & 0.63 & 1.04 & 0.097 & 1.06 & 0.61 & 1.84 & 0.830 \\
\hline & 3 & 0.45 & 0.31 & 0.65 & $<0.001$ & 0.41 & 0.15 & 1.09 & 0.075 \\
\hline & 4 and more & 0.77 & 0.53 & 1.12 & 0.179 & 0.71 & 0.29 & 1.77 & 0.469 \\
\hline \multirow[t]{2}{*}{ Congenital defect } & $\mathrm{no}=0$ & $1+$ & & & & $1+$ & & & \\
\hline & yes $=1$ & 2.66 & 1.55 & 4.57 & $<0.001$ & 2.16 & 0.64 & 7.28 & 0.215 \\
\hline \multirow[t]{2}{*}{ Medication } & no $=0$ & $1+$ & & & & $1+$ & & & \\
\hline & yes $=1$ & 2.65 & 1.69 & 4.14 & $<0.001$ & 3.07 & 1.32 & 7.15 & 0.009 \\
\hline \multirow[t]{4}{*}{ Apgar score $1 \mathrm{~min}$} & $8-10$ & $1+$ & & & & $1+$ & & & \\
\hline & $6-7$ & 2.20 & 1.01 & 4.79 & 0.047 & 2.41 & 1.09 & 5.36 & 0.030 \\
\hline & $4-5$ & 4.08 & 1.63 & 10.17 & 0.003 & 4.32 & 1.60 & 11.67 & 0.004 \\
\hline & $0-3$ & 6.79 & 2.40 & 19.24 & $<0.001$ & 6.74 & 2.32 & 19.61 & $<0.001$ \\
\hline \multirow[t]{2}{*}{ Genetic pathology } & no $=0$ & $1+$ & & & & $1+$ & & & \\
\hline & yes $=1$ & 19.41 & 7.52 & 50.14 & $<0.001$ & 26.68 & 7.64 & 93.12 & $<0.001$ \\
\hline
\end{tabular}

\section{RESULTS}

A total of 452 children aged 0-2 years were diagnosed with neoplastic disease in a study population comprising 730,000 live births $(0.62 / 1000)$ from 2000 - 2019. 51.1\% (231/452) of the patients with tumors were of male sex. In this study, 24\% (110/452) of tumors manifested in the neonates, 45\% (203/452) in infants, and 31\% (139/452) in toddlers 13-24 months. In total, (378/452) of tumors were malignant and $16 \%$ (74/452) benign. The most frequent malignant tumors were neuroblastomas, occurring in $18 \%(20 / 110)$ of neonates and 26\% (52/203) of infants. In toddlers aged 13-24 months, brain tumors were the most common group in $22 \%(30 / 139)$ of patients. The occurrence of tumors is shown in Table 1.

\section{Analysis of risk factors}

The occurrence and distribution of risk factors were compared between the tumor group $(n=452)$ and the control group of children without a tumor $(n=1279)$ (Table 2). The results of logistic regression analysis of risk factors showing significant differences are shown in Table 3.

Most tumors were found in children with mothers aged 25-29 years and fathers aged 30-34 years. The analysis did not identify differences between the paternal age groups or with respect to age differences between the parents. However, a difference between maternal age groups was identified; mothers of children with tumors were significantly younger but after adjusting for other factors, this was not confirmed to be significant.

Regarding internal risk factors, we found no significant differences with respect to parity, birth of twins, IVF, gestational week, size for gestational age, and AS at 5 and $10 \mathrm{~min}$. Although most tumors (45\%) were found in the first pregnancy, analysis using the adjusted model did not confirm significance. A lower AS at $1 \mathrm{~min}$. was associated with the increased risk of tumor development. In crude analysis, tumor incidence in all hypoxic categories was higher compared to non-altered newborns: mild asphyxia $(P=0.047$; OR 2.20 ; $95 \%$ CI $1.01-4.79)$, moderate asphyxia ( $P=0.003$; OR 4.08 ; 95\% CI $1.63-10.17)$, and 
Table 4. Additional data of tumor group.

\begin{tabular}{|c|c|}
\hline $\begin{array}{l}\text { Medications } \\
\text { used by mother } \\
\text { - case group } \\
(\mathrm{n}=38)\end{array}$ & $\begin{array}{l}\text { Hormonal treatment, progesterone } \\
\quad(n=15), \\
\text { anticoagulants }(n=8), \\
\text { antiepileptics }(n=6), \\
\text { autoimmune }(n=3), \\
\text { anti-allergic drugs }(n=2), \\
\text { psychiatric drugs }(n=1), \\
\text { corticoids }(n=1), \\
\text { chemotherapy }(n=1), \\
\text { antihypertension drugs }(n=1)\end{array}$ \\
\hline $\begin{array}{l}\text { Medications } \\
\text { used by mother } \\
\text { - control group } \\
(n=44)\end{array}$ & $\begin{array}{l}\text { Antihypertension drugs }(n=7), \\
\text { anticoagulants }(n=6), \\
\text { antiepileptics }(n=5), \\
\text { psychiatric drugs }(n=5), \\
\text { anti-allergic drugs }(n=4), \\
\text { corticoids }(n=4), \\
\text { antiaggregants }(n=4), \\
\text { hormonal treatment, progesterone } \\
\quad(n=4) \text {, } \\
\text { autoimmune }(n=2), \\
\text { antiviral treatment }(n=1), \\
\text { analgesics }(n=1), \\
\text { antiulcer treatment }(n=1)\end{array}$ \\
\hline $\begin{array}{l}\text { Congenital defects } \\
\text { - case group } \\
(n=26)\end{array}$ & $\begin{array}{l}\text { Kidney defect }(n=8) \text {, } \\
\text { heart defect }(n=6) \text {, } \\
\text { cheilognathopalatoschisis }(n=2) \text {, } \\
\text { hydrocephalus }(n=2) \text {, } \\
\text { limb defect }(n=4) \text {, } \\
\text { aplasia arteria umbilicalis }(n=2) \text {, } \\
\text { diaphragmatic hernia }(n=1) \text {, } \\
\text { macrocephaly }(n=1)\end{array}$ \\
\hline $\begin{array}{l}\text { Congenital defects } \\
\text { - control group } \\
(n=29)\end{array}$ & $\begin{array}{l}\text { aplasia arteria umbilicalis }(n=6) \text {, } \\
\text { kidney defect }(n=5) \text {, } \\
\text { heart defect }(n=5) \text {, } \\
\text { cheilognathopalatoschisis }(n=3) \text {, } \\
\text { limb defect }(n=3) \text {, } \\
\text { balanic hypospadias }(n=3) \text {, } \\
\text { macrocephaly }(n=2) \text {, } \\
\text { cryptorchidism }(n=2)\end{array}$ \\
\hline $\begin{array}{l}\text { Genetic syndromes } \\
\text { - case group } \\
(\mathrm{n}=32)\end{array}$ & $\begin{array}{l}\text { Trisomy } 21(n=7) \text {, } \\
\text { Neurofibromatosis NF } 1(n=7), \\
\text { Familiar retinoblastoma }(n=5), \\
\text { Tuberous sclerosis complex }(n=3), \\
\text { Beckwith-Wiedemann syndrome } \\
\quad(n=4), \\
\text { Shwachman-Diamond syndrome } \\
\quad(n=2), \\
\text { Pepper syndrome }(n=1), \\
\text { Costello syndrome }(n=1), \\
\text { STAR syndrome }(n=1), \\
\text { Waardenburger syndrome }(n=1)\end{array}$ \\
\hline $\begin{array}{l}\text { Genetic syndromes } \\
\text { - control group } \\
(\mathrm{n}=5)\end{array}$ & $\begin{array}{l}\text { Trisomy } 21(\mathrm{n}=2) \text {, } \\
\text { Beckwith-Wiedemann syndrome } \\
\quad(\mathrm{n}=1), \\
\text { Trisomy } 18(\mathrm{n}=1) \\
\text { Réthore syndrome }(\mathrm{n}=1)\end{array}$ \\
\hline
\end{tabular}

severe asphyxia ( $P<0.001$; OR 6.79; 95\% CI 2.40-19.24). The result in the adjusted model was, however, affected by a small sample size of the tumor group, yielding an insignificant result.

The presence of congenital malformations was also significantly associated with tumors $(P<0.001$; OR 2.66; $95 \%$ CI 1.55-4.57) in the crude analysis but after adjustment for other factors, this was not confirmed. The presence of any genetic disease was higher in the tumor group, even after adjustment for all factors $(P<0.001$; OR 26.68; 95\% CI 7.64-93.12). Renal defects were the most common congenital defects in the tumor group, and trisomy 21 was the most frequent genetic abnormality (Table 4). Morphological birth defects were further analyzed. The characteristics of their selected factors in both studied groups are given in Table 5. Apart from the higher incidence in the tumor group, no other differences were identified. A higher incidence of tumors was found in patients who died.

No differences were found between the groups with respect to smoking, alcohol consumption or drug use. The possible physical exposure effects are listed in Table 4; it was not possible to perform the analysis because of their low number. We confirmed the effect of maternal medication on the incidence of tumors ( $P=0.009$; OR 3.07; 95\% CI 1.32-7.15). Medications that the mothers used in the tumor and control group are also listed in Table 4.

\section{DISCUSSION}

In this study, we assessed the possible influence of selected risk factors on the development of cancer in young children, including an analysis of the effect of the parents' age. Over the last decades, the age of parents at first birth has been generally increasing ${ }^{14,15}$. Children of older parents are at higher risk of tumor development because of the possible accumulation of chromosomal aberrations and de novo mutations or hormonal changes dependent on maternal age. The effect of parental age on the development of oncological diseases has been reported previously. Older age of both mother and father was associated with an increased risk for childhood acute lymphoblastic leukemia; however, where acute myeloid leukemia is concerned, both older and younger mothers and fathers present a risk ${ }^{16}$. We did not confirm any significant effect of parental age or any effect of a difference in the age between the parents.

The effects of parity were also considered because of the different hormone levels in individual pregnancies. Estrogen and progesterone levels in maternal and umbilical cord blood are higher in the first pregnancy, and these hormones in utero may affect the development of tumors. Furthermore, the mother's immune response may differ between the first or subsequent pregnancy or childbirth ${ }^{17,18}$. The results of our study are similar to those of previous studies reporting a decreasing incidence of tumors with a higher number of pregnancies. This effect is most frequently observed for central nervous system tumors and neuroblastomas ${ }^{17,19,20}$. 
Table 5. The differences between selected risk factors of congenital defects.

\begin{tabular}{|c|c|c|c|c|c|c|c|c|c|c|c|c|}
\hline \multirow{2}{*}{$\begin{array}{l}\text { Congenital } \\
\text { defect }\end{array}$} & \multirow[t]{2}{*}{ Factors } & \multicolumn{5}{|c|}{ Tumor group $(\mathrm{n}=26)$} & \multicolumn{5}{|c|}{ Control group $(n=29)$} & \multirow[t]{2}{*}{$P^{*}$} \\
\hline & & $\mathrm{n}$ & mean $(\mathrm{SD})$ & median & $\min$ & $\max$ & $\mathrm{n}$ & mean $(\mathrm{SD})$ & median & $\min$ & $\max$ & \\
\hline \multirow[t]{6}{*}{ Kidney defect } & Birth weight & 8 & $3140.0(677.8)$ & 3175 & 1900 & 4100 & 5 & $2930.0(441.0)$ & 2800 & 2400 & 3500 & 0.463 \\
\hline & AS $1 \mathrm{~min}$ & 8 & $8.4(1.3)$ & 8 & 6 & 10 & 5 & $9.4(0.5)$ & 9 & 9 & 10 & 0.109 \\
\hline & AS $5 \mathrm{~min}$ & 8 & $9.9(0.4)$ & 10 & 9 & 10 & 5 & $9.4(0.5)$ & 9 & 9 & 10 & 0.083 \\
\hline & Gestational week & 8 & $38.3(2.7)$ & 39 & 32 & 41 & 5 & $37.2(2.2)$ & 36 & 35 & 40 & 0.371 \\
\hline & Age of mother & 8 & $31.1(9.0)$ & 29.5 & 22 & 52 & 5 & $33.0(2.9)$ & 34 & 29 & 36 & 0.142 \\
\hline & Age of father & 8 & $32.5(4.0)$ & 32.5 & 27 & 38 & 5 & $33.0(3.7)$ & 32 & 27 & 38 & 0.713 \\
\hline \multirow[t]{6}{*}{ Heart defect } & Birth weight & 6 & $3416.7(666.2)$ & 3420 & 2560 & 4500 & 5 & $3260.0(725.9)$ & 3280 & 2350 & 4100 & 0.784 \\
\hline & AS 1 min & 6 & $8.8(0.8)$ & 9 & 8 & 10 & 5 & $9.2(0.4)$ & 9 & 9 & 10 & 0.338 \\
\hline & AS 5 min & 6 & $8.8(1.5)$ & 9 & 6 & 10 & 5 & $10.0(0.0)$ & 10 & 10 & 10 & 0.032 \\
\hline & Gestational week & 6 & $38.5(1.6)$ & 39 & 36 & 40 & 5 & $38.0(2.8)$ & 39 & 35 & 41 & 0.852 \\
\hline & Age of mother & 6 & $30.3(3.5)$ & 30 & 26 & 36 & 5 & $32.0(4.2)$ & 34 & 25 & 35 & 0.521 \\
\hline & Age of father & 6 & $33.7(5.0)$ & 35.5 & 26 & 38 & 5 & $34.2(7.7)$ & 32.0 & 25 & 44 & 0.855 \\
\hline \multirow[t]{6}{*}{ Limb defect } & Birth weight & 4 & $2860.0(399.6)$ & 2905 & 2380 & 3250 & 3 & $2816.7(636.1)$ & 2680 & 2260 & 3510 & 0.724 \\
\hline & AS $1 \mathrm{~min}$ & 4 & $9.8(0.5)$ & 10 & 9 & 10 & 3 & $9.3(1.2)$ & 10 & 8 & 10 & 0.659 \\
\hline & AS $5 \mathrm{~min}$ & 4 & $10.0(0.0)$ & 10 & 10 & 10 & 3 & $9.7(0.6)$ & 10 & 9 & 10 & 0.248 \\
\hline & Gestational week & 4 & $37.8(2.6)$ & 38 & 35 & 40 & 3 & $39.0(1.0)$ & 39 & 38 & 40 & 0.714 \\
\hline & Age of mother & 4 & $30.0(2.7)$ & 31 & 26 & 32 & 3 & $29.3(4.7)$ & 31 & 24 & 33 & 1.000 \\
\hline & Age of father & 4 & $33.8(3.2)$ & 33.5 & 31 & 37 & 3 & $30.3(2.1)$ & 31 & 28 & 32 & 0.271 \\
\hline \multirow{6}{*}{$\begin{array}{l}\text { Cheilo-gnatho- } \\
\text { palato-schisis }\end{array}$} & Birth weight & 2 & $2905.0(77.8)$ & 2905 & 2850 & 2960 & 3 & $3040.0(1154.7)$ & 2920 & 1950 & 4250 & N/A \\
\hline & AS 1 min & 2 & $8.0(0.0)$ & 8 & 8 & 8 & 3 & $8.7(0.6)$ & 9 & 8 & 9 & \\
\hline & AS 5 min & 2 & $10.0(0.0)$ & 10 & 10 & 10 & 3 & $10.0(0.0)$ & 10 & 10 & 10 & \\
\hline & Gestational week & 2 & $30.5(0.0)$ & 38.5 & 38 & 39 & 3 & $37.7(3.5)$ & 38 & 34 & 41 & \\
\hline & Age of mother & 2 & $30.3(3.5)$ & 35 & 26 & 36 & 3 & $31.7(3.2)$ & 33 & 28 & 34 & \\
\hline & Age of father & 2 & $30.5(6.4)$ & 30.5 & 26 & 35 & 3 & $37.3(3.2)$ & 36 & 35 & 41 & \\
\hline \multirow{6}{*}{$\begin{array}{l}\text { Aplasia arteria } \\
\text { umbilicalis }\end{array}$} & Birth weight & 2 & $3545.0(289.9)$ & 3545 & 3340 & 3750 & 6 & $3278.3(454.0)$ & 3440 & 2700 & 3820 & $\mathrm{~N} / \mathrm{A}$ \\
\hline & AS $1 \mathrm{~min}$ & 2 & $10.0(0.0)$ & 10 & 10 & 10 & 6 & $9.3(0.8)$ & 9.5 & 8 & 10 & \\
\hline & AS 5 min & 2 & $10.0(0.0)$ & 10 & 10 & 10 & 6 & $10.0(0.0)$ & 10 & 10 & 10 & \\
\hline & Gestational week & 2 & $39.5(0.7)$ & 39.5 & 39 & 40 & 6 & $39.0(1.5)$ & 39.5 & 36 & 40 & \\
\hline & Age of mother & 2 & $31.5(0.7)$ & 31.5 & 31 & 32 & 6 & $28.3(1.6)$ & 28.5 & 26 & 30 & \\
\hline & Age of father & 2 & $34.5(0.7)$ & 34.5 & 34 & 35 & 6 & $30.0(4.9)$ & 30.5 & 23 & 36 & \\
\hline \multirow[t]{6}{*}{ Others } & Birth weight & 4 & $3615.0(229.6)$ & 3635 & 3340 & 3580 & 7 & $3261.4(373.2)$ & 3260 & 2800 & 3950 & N/A \\
\hline & AS $1 \mathrm{~min}$ & 4 & $7.8(2.6)$ & 8.0 & 5 & 10 & 7 & $8.7(1.3)$ & 9.0 & 6 & 10 & \\
\hline & AS $5 \mathrm{~min}$ & 4 & $9.0(1.4)$ & 9.5 & 7 & 10 & 7 & $9.6(0.8)$ & 10 & 8 & 10 & \\
\hline & Gestational week & 4 & $39.5(0.6)$ & 39.5 & 39 & 40 & 7 & $38.9(1.5)$ & 39.0 & 36 & 40 & \\
\hline & Age of mother & 4 & $29.3(2.8)$ & 29.5 & 26 & 32 & 7 & $32.4(6.7)$ & 33.0 & 22 & 43 & \\
\hline & Age of father & 4 & $32.0(3.6)$ & 33.0 & 27 & 35 & 7 & $38.0(9.5)$ & 35.0 & 27 & 55 & \\
\hline
\end{tabular}

*The results were compared by the Two-sample Mann-Whitney test, the test was performed only if there were 3 or more patients in both groups; N/A - not applicable

Others: In the group of tumors-hydrocephalus $(n=2)$, diaphragmatic hernia $(n=1)$, macrocephaly $(n=1)$; in the control group-macrocephaly ( $n=2)$, balanic hypospadia $(n=3)$, cryptorchidism $(n=2)$

Post-IVF children are a special group. Many studies and meta-analyses have addressed the potential risk of cancer in children, but no clear and convincing conclusion has been reached so far $^{21,22}$. Our results have not proved that methods of assisted reproduction would be a risk factor for tumors in children up to 2 years of age, either.

The birth weight or trophic status of a child is also considered a risk factor. Children's weight has been increasing, probably due to the increasing weight of mothers, and maternal obesity is one of the potential risk factors for childhood tumors ${ }^{23,24}$. We did not confirm a significant effect of net birth weight on the development of tumors in children under 2 years of age, but there is evidence of an increased risk of developing tumors with increased birth weight ${ }^{25}$. Fetal growth is a risk factor that is more important than birth weight alone. The relationship between accelerated fetal growth and certain types of childhood tumors has already been described ${ }^{26}$. Studies have shown that children born LGA or SGA are at a higher risk of childhood tumors. In this cohort, we did not find any effect of SGA or LGA on tumor development.

The effect of postnatal adaptation on the incidence of tumors is also discussed. The AS at 5 min appears to be the most important factor for infant mortality and morbidity. A low neonatal score at $5 \mathrm{~min}$ was reported to be possibly associated with tumors, most commonly renal tumors ${ }^{27-30}$. In our study, a low AS at $1 \mathrm{~min}$ was significant for the occurrence of tumors. This relationship was, however, confirmed only in the crude analysis since 
the adjusted model could not be calculated due to the low sample size. No association with a low AS at 5 and 10 min was detected.

Congenital malformations and genetic abnormalities are associated with a higher incidence of pediatric tumors $^{31}$. In the presented study, tumors were also significantly associated with other birth defects, genetic pathologies, and death. We tried to perform a more detailed analysis of congenital defects. However, apart from the higher incidence, we did not find any other differences between the tumor and the control group. This might have, however, been caused by the low numbers of individual defects and, therefore, low power of the statistical analysis

Regarding environmental and potential exposure factors, we evaluated the effects of smoking, medications, illicit drugs, alcohol, and potential toxins in the mothers. The effect of female infertility treatment is considered the most important factor ${ }^{32}$. Epigenetic changes induced by repeated hormonal stimulation may be a potential mechanism of tumor development. We confirmed the effect of the drugs on the incidence of tumors in our study. Our drug group was dominated by hormone treatment with progesterone. Sex hormones are considered potential carcinogens, and repeated exposure to these drugs thus may, therefore, represent one of the possible causes of tumor development ${ }^{33}$.

The carcinogenic effect of tobacco is well known, and its effect on childhood tumors is still under investigation. The risk of retinoblastoma, neuroblastoma, and certain types of brain tumors is associated with maternal smoking $^{34-36}$. However, we did not confirm any significant effect of smoking on tumor development in this study.

Currently, alcohol consumption is significantly increasing. In the case of occasional alcohol consumption during pregnancy, the risk of developing tumors does not differ from that in a normal population ${ }^{37}$. Illicit drugs may play an important role in the development of tumors such as neuroblastoma ${ }^{38}$. We, however, did not confirm these effects.

The strengths of the present study are a long study period in a large region with a stable birth rate and knowledge of all cancers in the observed population. Limitations include the possibility of missing data in the case of incomplete case histories; in this study, this happened when assessing the effect of AS. Second, we cannot fully exclude a potential methodology bias for the following reasons: i) data only from two registries (neonatology and oncology) were analyzed; ii) the final diagnoses were established by several pathologists, iii) there was an absence of central review in cases of non-malignant tumors; iv) the potential effect of environmental and lifestyle risk factors was not taken into account.

\section{CONCLUSION}

Risk factors for the development of early childhood tumors could be identified, with medications used by the mother before or during pregnancy, and associated ge- netic diseases appearing to carry the highest risk. Other factors included a younger age of the mother, a lower parity, perinatal asphyxia, and the presence of other significant noncancerous diseases.

Acknowledgment: This work has been supported by the Czech Ministry of Health, grant no NU20-03-00240. This work was supported by the Faculty Hospital in Hradec Kralove (a long-term organization development plan).

This work was supported by the European Regional Development Fund - Project ENOCH (No. CZ.02.1.01 /0.0/0.0/16_019/0000868).

We acknowledge the CF Genomics of CEITEC supported by the NCMG research infrastructure (LM2015091 funded by MEYS CR) for their support with obtaining scientific data presented in this article.

Author contributions: HW, PM, JP: conception and study design, data collection, data analysis, manuscript writing, literature research; HT: data analysis; AH, HP, PV: data collection, reviewing and revising manuscript; OS, JS: reviewing and revising manuscript, responsibility for final approval.

Conflict of interest statement: The authors state that there are no conflicts of interest regarding the publication of this article.

\section{REFERENCES}

1. Desandes E, Clavel J, Berger C, Bernard JL, Blouin P, Lumley L, Demeocq F, Freycon F, Gembara P, Goubin A, Le Gall E, Pillon P, Sommelet D, Tron I, Lacour B. Cancer incidence among children in France, 1990-1999. Pediatr Blood Cancer 2004;43(7):49-57.

2. Li J, Thompson TD, Miller JW, Pollack LA, Stewart SL. Cancer incidence among children and adolescents in the United States, 2001 2003. Pediatrics 2008;121(6):e1470-77.

3. Baade PD, Youlden DR, Valery PC, Hassall T, Ward L, Green AC, Aitken JF. Trends in incidence of childhood cancer in Australia, 1983-2006. Brit J Cancer 2010;102(3):620-6.

4. Moore SW, Satge D, Sasco A, Zimmermann A, Plaschkes J. The epidemiology of neonatal tumors. Pediatr Surg Int 2003;19(7):509-19.

5. Moore SW. Neonatal tumors. Pediatr Surg Int 2013;29(12):1217-29.

6. Rennie JM. Rennie \& Roberton's textbook of neonatology e-book. 5th ed. Edinburgh: Churchill Livingstone; 2012

7. Desandes E, Guissou S, Ducassou S, Lacour B. Neonatal solid tumors: incidence and survival in France. Pediatr Blood Cancer 2016;63(8):1375-80.

8. Mettling, K, Murcek K, Rubarth CB. Column Title: Malignancies and Tumors in the Neonate. Neonatal Network 2013;32(1):34-40.

9. Spector LG, Pankratz N, Marcotte EL. Genetic and Nongenetic Risk Factors for Childhood Cancer. Pediatr Clin N Am 2015;62(1):11-25.

10. Lin TF, Huang B, Robbins E. Congenital malignant disorders. In: Gleason CA, Juul SE, eds. Avery's Diseases of the Newborn. Philadelphia, PA: 10th ed. Elsevier; 2018. p.1219-37

11. Parson DW, Angshumoy R, Yaping $Y$, Wang T, Scollon S, Bergstrom $K$ Kerstein RA, Gitierrez S, Petersen AK, Bavle A, Lin FY, López-Terrada $\mathrm{DH}$, Monzon FA, Hicks MJ, Eldin KW, Quintanilla NM, Adesina AM, Mohila CA, Whitehead W, Jea A, Vasudevan SA, Nuchtern JG, Ramamurthy U, McGuire AL, Hilsenbeck SG, Reid JG, Muzny DM, Wheeler DA, Berg SL, Chintagumpala MM, Eng CM, Gibbs RA, Plon SE.Diagnostic Yield of Clinical Tumor and Germline WholeExome Sequencing for Children With Solid Tumors. JAMA Oncol 2016;2(5):616-24.

12. Zhang J, Walsh MF, Wu G, Edmonson MN, Gruber TA, Easton J, Hedges D, Ma X, Zhou X,Yergeau DA, Wilkinson MR, Vadodaria B, Chen X, McGee RB, Hines-Dowell S, Nuccio R, Quinn E, Shurtleff SA, Rusch M, Patel A, Becksfort JB, Wang S, Weaver MS, Ding L, Mardis 
ER, Wilson RK, Gajjar A, Ellison DW, Pappo AS, Pui CH, Nichols $\mathrm{KE}$, Downing JR. Germline Mutations in Predisposition Genes in Pediatric Cancer. New Engl J Med 2015;373(24):2336-46.

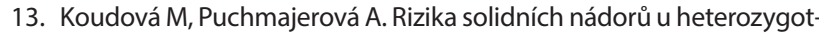
ních přenašečů recesivních syndromů, Klin Onkol 2019;Suppl2:2S14$2 S 23$.

14. Contreras ZA, Hansen J, Ritz B, Olsen J, Yu F, Heck JE. Parental age and childhood cancer risk: A Danish population-based registry study. Cancer Epidemiol 2017;49:202-15.

15. Wang R, Metayer C, Morimoto L, Wiemels JL, Yang J, DeWan AT, Kang A, Ma X. Parental age and risk of pediatric cancer in the offspring: a population-based record-linkage study in California. Am J Epidemio 2017;186(7):843-56.

16. Sergentanis TN, Thomopoulos TP, Gialamas SP, Karalexi MA, BiniarisGeorgallis SI, Kontogeorgi E, Papathoma P, Tsilimidos G, Skalkidou A, Iliadou AN, Petridou ET. Risk for childhood leukemia associated with maternal and paternal age. Eur J Epidemiol 2015;30(12):1229-61.

17. Von Behren J, Spector LG, Mueller BA, Carozza SE, Chow EJ, Fox EE, Horel S, Johnson KJ, McLaughlin C, Puumala SE, Ross JA, Reynolds P. Birth order and risk of childhood cancer: a pooled analysis from five US States. Int J Cancer 2011;128(11):2709-16.

18. Schüz J, Luta G, Erdmann F, Ferro G, Bautz A, Simony SB, Dalton SO, Lightfoot T, Winther JFBirth order and risk of childhood cancer in the Danish birth cohort of 1973-2010. Cancer Cause Control 2015;26(11):1575-82.

19. Linet MS, Gridley G, Cnattingius S, Nicholson HS, Martinsson U, Glimelius B, Adami HO, Zack M. Maternal and perinatal risk factors for childhood brain tumors (Sweden). Cancer Cause Control 1996;7(4):437-48.

20. Rios P, Bailey HD, Orsi L, Lacour B, Valteau-Couanet D, Levy D, Corradini N, Leverger G, Defachelles AS, Gambart M, Sirvent N Thebaud E, Ducassou S, Clavel J. Risk of neuroblastoma, birth-related characteristics, congenital malformations and perinatal exposures: A pooled analysis of the ESCALE and ESTELLE French studies (SFCE). Int J Cancer 2016;139(9):1936-48.

21. Gilboa D, Koren G, Barer Y, Katz R, Rotem R, Lunenfeld E, Shalev V. Assisted reproductive technology and the risk of pediatric cancer: $A$ population based study and a systematic review and meta analysis. Cancer Epidemiol 2019;63:101613.

22. Levi-Setti PE, Patrizio P. Assisted reproductive technologies (ART) and childhood cancer: is the risk real? J Assist Reprod Gen 2018;35(10):1773-75.

23. Stacy SL, Buchanich JM, Ma ZQ, Mair C, Robertson L, Sharma RK Talbott EO, Yuan JM. Maternal obesity, birth size, and risk of childhood cancer development. Am J Epidemiol 2019;188(8):1503-11.

24. Caughey RW, Michels KB. Birth weight and childhood leukemia: a meta-analysis and review of the current evidence. Int J Cancer 2009;124(11):2658-70.

25. O'Neill KA, Murphy MF, Bunch KJ, Puumala SE, Carozza SE, Chow EJ, Mueller BA, McLaughlin CC, Reynolds P, Vincent TJ, Von Behren J, Spector LG. Infant birthweight and risk of childhood cancer: inter- national population-based case control studies of 40000 cases. Int J Epidemiol 2015;44(1):153-68.

26. Milne E, Greenop KR, Metayer C, Schüz J, Petridou E, Pombo-deOliveira MS, Infante-Rivard C, Roman E, Dockerty JD, Spector LG, Koifman S, Orsi L, Rudant J, Dessypris N, Simpson J, Lightfoot T, Kaatsch P, Baka M, Faro A, Armstrong BK, Clavel J, Buffler PA. Fetal growth and childhood acute lymphoblastic leukemia: findings from the childhood leukemia international consortium. Int J Cancer 2013;133(12):2968-79.

27. Schüz J, Schmidt LS, Kogner P, Lähteenmäki PM, Pal N, Stokland T, Schmiegelow K. Birth characteristics and Wilms tumors in children in the Nordic countries: A register-based case-control study. Int J Cancer 2011;128(9):2166-73.

28. Li J, Cnattingus S, Gissler M, Vestergaard M, Obel C, Ahrensberg J, Olsen J. The 5-minute Apgar score as a predictor of childhood cancer: a population-based cohort study in five million children. BMJ Open 2012;2(4):e001095.

29. de Paula Silva N, de Souza Reis R, Garcia Cunha R, Pinto Oliveira JF, Santos MO, Pombo-de-Oliveira MS, de Camargo B, Rota R. Maternal and birth characteristics and childhood embryonal solid tumors: a population-based report from Brazil. Plos One 2016;11(10):e0164398.

30. Bhattacharya S, Beasley M, Pang D, Macfarlane GJ. Maternal and perinatal risk factors for childhood cancer: record linkage study. BMJ Open 2014;4(1):e003656. doi: 10.1136/bmjopen-2013-003656

31. Altmann AE, Halliday JL, Giles GG. Associations between congenital malformations and childhood cancer. A regis,ter-based case-control study. Brit J Cancer 1998,78(9):1244-9.

32. Hargreave M, Jensen A, Toender A, Andersen KK, Kjaer SK. Fertility treatment and childhood cancer risk: a systematic meta-analysis. Fertil Steril 2013;100(1):150-61.

33. Hargreave $M$, Jensen A, Nielsen TS, Colov EP, Andersen KK, Pinborg A, Kjaer SK. Maternal use of fertility drugs and risk of cancer in children-A nationwide population-based cohort study in Denmark. Int J Cancer 2015;136(8):1931-39.

34. Tettamanti G, Ljung R, Mathiesen T, Schwartzbaum J, Feychting M. Maternal smoking during pregnancy and the risk of childhood brain tumors: Results from a Swedish cohort study. Cancer Epidemiol 2016;40:67-72.

35. Heck JE, Contreras ZA, Park AS, Davidson TB, Cockburn M, Ritz B. Smoking in pregnancy and risk of cancer among young children: $A$ population-based study. Int J Cancer 2016;139(3):613-16.

36. Chu P, Wang H, Han S, Jin Y, Lu J, Han W, Shi J, Guo Y, Ni X. Maternal smoking during pregnancy and risk of childhood neuroblastoma: Systematic review and meta-analysis. J Cancer Res Ther 2016;12(2):999.

37. Schuz J, Kaatsch P, Kaletsch U, Meinert R, Michaelis J. Association of childhood cancer with factors related to pregnancy and birth. Int J Epidemiol 1999;28(4):631-39.

38. Müller-Schulte E, Kurlemann G, Harder A. Tobacco, alcohol and illicit drugs during pregnancy and risk of neuroblastoma: systematic review. Arch Dis Child-Fetal 2018;103(5):F467-F473. 